\title{
The Rationale of the Administrative Thought of ALI BIN ABI TALIB and Administrative Schools (A Comparative Study)
}

\author{
Youssef CHAHINE \\ Assistant Professor, Lebanese University \\ Faculty of Economics and Business Administration - Branch 5 \\ E-mail: ychahine@ul.edu.lb
}

Received: Jan. 9, 2020 Accepted: Feb. 10, 2020 Online published: Feb. 17, 2020

doi:10.5296/jpag.v10i1.16490～URL: https://doi.org/10.5296/jpag.v10i1.16490

\begin{abstract}
This paper discussed a set of theoretical and administrative hypothesis of schools of administration, which contributed to influence the science of management in general and led to the emanation of many models associated with the means of management and its fundamentals. These schools relied on the use of various hypotheses or theories that sought to develop a knowledge structure of management that could contribute to solving administrative problems, especially at the end of the nineteenth century, which witnessed the development of management science through scientists and eggheads.

Moreover there was an odd experience at the level of administration and governance, revealing the unique mentality of Ali in management, in the legal, comprehensive and humanitarian ones, which printed the terms of his reign to Malik - decibel and companion of Ali - some related to economic matters political, social issues deal with the duties and functions of the ruler and relations between the ruler and the parish.

We concluded that the management materials provided by all known administrative schools testify unequivocally to the thought of Ali, addressing the administration from the perspective of building the land on the basis of justice, efficiency and equity. Therefore, we consider that venerable scholars, whatever their religion, creed or race, are just witnesses to the correctness, validity and comprehensiveness of Ali's thought, not only in the twenty-first century, but we can say objectively as a testimony to all ages.
\end{abstract}

Keywords: administration, censorship, humanitarian governance, justice, leadership, management, orientation, productivity, social solidarity 


\section{Introduction}

Most of the administrators exerted a great effort in developing and enhancing contemporary administrative thought. As a result of their research, efforts, experiences, ideas and discussions, which resulted in various administrative theories, several schools concerned with administrative thought emerged. These schools, through theories and ideas, painted the features of good management in terms of principles and philosophies.

Administrative thought is a set of topics that concern the management of individuals and the organization of work in private and public institutions, and with the emergence of schools of thought, which relied on the treatment of human relations and concerned with the study of methods of work and organization emanated the importance of administrative thought aimed at achieving benefits within an intellectual ambience interested in knowing the factors affecting it in different directions, contents and forms.

In this paper we will discuss a set of theoretical and administrative hypothesis of these schools, which contributed to influence the science of management in general and led to the emanation of many models associated with the means of management and its fundamentals.

In the study of individuals and organizations, these schools relied on the use of various hypotheses or theories that sought to develop a knowledge structure of management that could contribute to solving administrative problems, especially at the end of the nineteenth century, which witnessed the development of management science through scientists and eggheads who were interested in studying this domain without full agreement on determining the limits, which led to the appearance of a clear difference of opinions.

With the development of industry and the multiplicity of standards of production, these schools existed to respond to the requirements of successful work for each individual and at the level of the company itself and the positive repercussions on the economic situation because good governance derives its vitality from its economies, featured as a set of ideas on the tongues of dignified scientists who helped cover the crisis It is no wonder if developed countries are the first to base management on science and performance, perhaps we can say that progress is the result of advanced management. Underdevelopment is the product of unenlightened management.

The administration is to manage, guide, and organize the affairs of the people in order to enable them to carry out the tasks assigned to them and to implement the plans established for them in order to preserve their entity and ensure the continuity of their presence (Hubeish, 1991).

There is a an odd experience at the level of administration and governance, revealing the unique mentality of Ali in management, in the legal, comprehensive and humanitarian ones, which printed the terms of his reign to Malik - decibel and companion of Ali - some related to economic matters and some political military-social issues deal with the duties and functions of the ruler and relations between the ruler and the parish and preview Governors as the first step in calling to account, and the importance of time in knowledge productivity and budget control in countries and institutions, as well as social solidarity within them as well as the 
impact of business in the economy and work ethics. This was presented by Ali bin Abi Talib in his reign to Malik al-Ashtar when he applied him governor of Egypt, which represents a comprehensive constitution that draws people their rights and guarantees their interests and diagnoses the duties of the state towards them in various fields.

It is a precise of the principles of administration and justice. It deals with duties and obligation of rulers, their main responsibilities, the question of priorities of rights and obligations, dispensation of justice; control over secretaries and subordinate staff; distribution of work and duties among the various branches of administration, their coordination with each other, cooperation with the center. This paper is divided into four sections. The first section is the introduction. The second section deals with the most important administrative schools in the world. In the third section, we will explore in depth the thought of Ali on how to reach good governance and what are the necessary controls to maintain it from deviation and error. We will make the conclusion in the fourth section.

\section{Intellectual Schools}

Administrative thought is a set of topics that are concerned with the study of the management of individuals and the organization of administrative work has been associated with the existence of schools of thought management, which relied on addressing human relations and attention to scientific management through the study of methods of work and organization. In this section, we will present the most important intellectual management schools in the world.

\subsection{Classical School (1890-1930)}

It appeared in the early twentieth century and includes several theories differing in the details of its approach to access to theories and administrative principles, but it agrees in its assumptions of what is human as an economic object only, and assumes that the behavior is consistent with the requirements and decisions of management.

This school tried, through the efforts of a group of researchers, to address administrative problems on a scientific basis with the need to move away from the concepts of trial, error, intuition and guesswork. The results of research and studies have led to the emergence of a basic approach to management with a divergence of views through the establishment of three theories reflected in the intellectual trends of the pioneers of this school, namely the theory of scientific management and the theory of administrative divisions and bureaucratic theory.

\subsubsection{Scientific Management}

At the beginning of the twentieth century, the movement of scientific management arose through the American engineer Frederick Taylor, who is known by some as the father of the administration or its pioneer as the first who established the application of scientific foundations to study the performance of the worker through experiments and research conducted in many American factories through which he reached the results determined by the figures. With a large percentage of material resources and human efforts wasted in doing business because of the lack of rates and standards and the lack of wages linked to production and personal effort, Taylor found that workers are doing their utmost to increase productivity 


\section{MlMacrothink}

Journal of Public Administration and Governance

ISSN 2161-7104

2020, Vol. 10, No. 1

but lack motivation in addition to the payment of wages on the basis of the piece and that employers relied on reducing the wage piece rate with increases in production and thus the negative factor has become more acute, according to the policy of payment compared to a freelancer cash payment (Taylor, 1911). In his research, Taylor faced a fundamental problem that would enable him to determine what a worker should produce daily and is economically acceptable from the point of view of the worker and management. The policy followed scientifically in measuring production was random, so Taylor divided the work into a group of elements and measured the time required for each element and then analyzes the work and the elements in terms of both physical and human in order to reach clear scientific criteria for the method and quantity of production expected from each worker.

As a result of his study of time and movement, Taylor managed to increase production more than what it was before his studies, and in return increased the wage earned by the worker and thus achieved the most important goals of raising productivity and wage as well as reducing the cost of the unit produced. Accordingly, Taylor's philosophy shows that the only important element of scientific management is the idea of the task (work) and that everyone must be planned by the administration in advance and that everyone receives his instructions in full written details describing the task to be accomplished and the methods to be used, the task does not only determine the work but the method that must be used but the time allowed to be accomplished. Here are four basic principles:

a- Studying the various processes in terms of the transactions to be completed and the time taken to complete them and to determine the optimal methods of performance.

b- Determine the standard rate of production that should be achieved by the task.

c- Scientific selection of workers.

d- Separation of planning and implementation, where the leader is in charge of the planning process, while the role of the worker is determined in the implementation.

\subsubsection{Administrative Divisions}

In the meantime the principles of scientific management in the United States began to take their place in the studies and administrative work, Henry Fayol, who was considered by some founder of the theory of administrative divisions by focusing on the concept of management in a more holistic view, focused on finding a set of principles based on real quantities. This is mentioned in his book General Industrial Management, where Fayol divided the administration into two parts, the first concerned with the principles of management and the second to ensure its functions (Taylor, 1911). So, Henry Fayol's management thought can be identified or summarized in three main aspects:

a- Developing an integrated scientific concept for the manager's job (planning, organizing, leading, issuing orders, coordinating, controlling).

b- Determining the activities of business organizations (technical, commercial, financial, security, administrative ...). 
c- Determining the fourteen principles that guide the Director in carrying out his job such as division of work, equalization of authority and responsibility, discipline and discipline, unity of command, fair pay, hierarchy of power, equality of treatment, staff stability, team spirit, providing a spirit of initiative and innovation.

\subsubsection{Bureaucracy}

The word bureaucracy means the authority of the office, i.e. the authority derived from the office because the word is composed of two parts, the first Bureau, the office and the second "Cracy" means authority.

Many people explain the word bureaucracy contrary to its original meaning. They have linked the concept of bureaucracy to the notion of routine, but basically the opposite, since the bureaucracy is aimed at eliminating personal character.

Max Weber, a German sociologist, has presented a model of institutions or a management system based on strict rules and procedures as well as a clear division of labor (the comprehensiveness of systems, rules and divisions for the public interest) where the proper functioning of the work requires full knowledge of the worker in his job. (Weber, 1949).

From Max Weber point of view, the organization is a hierarchy of power from the top down and the organization relies on documents, papers and writings in everything with the comprehensiveness of the regulations, rules and instructions and their relative stability for the public interest.

In this sense of the bureaucratic model, Weber believes that the aim of the job is to achieve the public interest avoiding the possibility of achieving individual self-interest in order to provide the maximum production efficiency in government institutions and agencies because of their positive impact on economic growth in industrialized and developing countries, in addition to focusing on the type of means, so as not to become ends. For Max Weber, bureaucracy simply means sequential social construction to manage large organizations in a sound, efficient, effective, and impersonal manner.

\subsection{Behavioral and Humanistic School (1930-1960)}

This school represents a set of ideas and insights emphasize that good performance is linked to behavioral and human variables. It is an applied scientific school, based on the development of hypotheses about organizational behavior and its impact on productivity and then examines these hypotheses in a scientific manner and applies the results in the work environment. It is also a normative school based on value standards aimed at the application of behavioral research in the field of work in order to bring about a change in specific behavioral attitudes.

The Behavioral and Humanitarian School originated in the United States of America and focused its attention on the study of individual and group behavior as a central focus in achieving work to increase productivity by analyzing the interplay between environmental factors and individuals and its reflection on human behavior, using three approaches to the study of behavior. 
The first is psychology and its branches (commercial / industrial), the second is sociology and the third is anthropology which focuses on patterns of human behavior. The pioneers of this school are Elton Mayo, Mary Parker Violet, Chester Bernard, R. Lekhart and Douglas McGregor who have contributed significantly to the activation of organizational performance. This school includes "Human relations movement" through studies and experiments conducted by Elton Mayo in Hawthorne factories in the United States of America in 1927, which formed the starting point for the attention of the human side in the administration and believes that managers should use good human relations to reach higher productivity by workers, and these experiences centered the extent to which working conditions affect the productivity of the worker. It was aimed at knowing the correlation of physical factors motivating productivity because the worker is an economic being that responds directly to the incentives and the result of low morale accompanied by many complaints resulting from fatigue and thus a sense of unhappiness. Rest periods during the daily work with the participation of workers in the opinions and administrative decisions, which reflected positively on improving the performance of the worker and raises the level of production and thus increase in income. One can summarize what was mentioned before in the following formula.

\section{Productivity Sufficiency $=($ Ability $\times$ Training $\times$ Motivation $)-$ Fatigue}

The findings of May through experiments are summarized as follows:

a- Motivation of the individual is not only by material incentives but moral incentives which have a significant role in raising the incentive of individuals.

b- Focus on the democratic approach and participation as a style of administrative leadership.

c- Managers need social skills as well as technical skills.

d- Linking the satisfaction of the individual worker and productivity, where workers can be motivated by achieving their psychological and social needs.

However Marie Violet appealed to the application of the principle of joint force rather than authoritarian power. In her view, achieving the highest efficiency in work, either through integration of activities, is a reason for delegation of authority, especially with the size of institutions and the increasing need for specialized expertise to deal with integrated activities. For violence and power, Violet opposed the traditional bureaucratic role of power. Power is the ability to accomplish, while authority is the right of the individual regardless of his or her organizational status to exercise this power.

Chester Bernard focused on the importance of individual behavior and was concerned with the organizational structure theory, mentioning that the individual is fully prepared to accept orders, instructions and directives without resistance if they are available in the communication structure that includes clear, understandable and comprehensible messages by individuals without contradicting their personal goals of the individual simultaneously with ensuring the mental and physical ability of the individual to execute. These messages, the 
shorter the line, the more errors will be avoided and the work will be done quickly and completely (Barnard, 1968).

R. Lekhart considered that the organization is not only an organizational structure that includes a group of departments and sections, but groups of workers linked to each other from the lowest to the top of the organization, i.e. in terms of work style and decision-making must take into account the philosophy of teamwork and participation. Leadership, according to Lekhart's interpretation, cares about work and cares about people. Consequently caring for work and people helps the organization in increasing productivity and raises the spirits of individuals.

Abraham Lincoln says: "You can empower people sometimes and you can empower some people at all times, but it's hard to empower all people at all times."

Douglas McGregor focused on motivation and behavior in institutions and saw through his studies that leaders treat their subordinates as irresponsible individuals and do not like work. This is called the theory of $\mathrm{X}$ and on the opposite side is the Y-mode which assumes that individuals tend to love work (Kopelman, 2011).

Therefore, he appealed to managers to deal positively with individuals and their social needs, especially to work to provide a climate or conditions that make individuals reflect their abilities to work and leave a margin of freedom and responsibility for the completion of the work that requires individuals to conform to their wishes and contribute to the achievement of organizational goals in general.

The following hypotheses are based on his theory.

Table 1. Null and alternative hypothesis

\begin{tabular}{|l|l|}
\hline Null hypothesis & Alternative hypothesis \\
\hline $\begin{array}{l}\text { 1. Most individuals do not like to work. } \\
\text { 1. Individuals love to work. }\end{array}$ \\
$\begin{array}{l}\text { 2. Individuals must be monitored and } \\
\text { threatened to drive them to achievement and } \\
\text { performance. }\end{array}$ & $\begin{array}{l}\text { 2. External control and threat are not the } \\
\text { effective element of the effort. }\end{array}$ \\
\hline $\begin{array}{l}\text { 3. Individuals tend to avoid responsibility. } \\
\text { 3. Financial incentives are the main } \\
\text { responsibility. } \\
\text { motivation for action. }\end{array}$ & $\begin{array}{l}\text { 4. Moral incentives have an essential role in } \\
\text { motivating individuals to do good work. }\end{array}$ \\
\hline $\begin{array}{l}\text { 5. Most individuals are not creative and } \\
\text { cannot solve problems. }\end{array}$ & $\begin{array}{l}\text { 5. Individuals have the ability to imagine and } \\
\text { innovate to solve problems. }\end{array}$ \\
\hline
\end{tabular}


This theory made the questionnaire wide-opened as we understand through the hypotheses of zero and alternative and this needs to investigate information through the examination of individuals and get their opinions accurately.

Therefore, since management involves doing things with and through people, their study should be focused on human interpersonal relationships, meaning that people where they work together as groups to achieve goals. Consequently it is necessary for people to understand each other because and according to logicians there is an entire relation between human relations and the administration in general.

\subsection{The Modern School (1960)}

Recent studies and theories have emerged in their content as a scientific addition to the previous schools in order to develop management by focusing on different approaches as a complementary link in the activation of administrative practice as well as administrative performance.

\subsubsection{School of Management Science}

The School of Management Science was established as a result of World War II research and dealt mainly with the application of quantitative methods in military fields, and problems related to transport and distribution. The problems were addressed by a team of members with different backgrounds i.e. overlapping a number of branches of knowledge (engineers / mathematicians). / Statisticians / Economists)

This school has reconciled the scientific management's interest in production and efficiency with the planning process by integrating several fields of knowledge, particularly quantitative methods to address the problems facing administrators and institutions. Management scientists use mathematical and computer models to perform complex mathematical and mathematical operations to help obtain to achieve optimal objectives such as linear programming, waiting lines or lines and decision theories applied in many areas to solve management problems.

This school is based on the fact that mathematics and quantitative methods can be used to improve the quality of decisions and problem-solving in the business organization as follows:

-Operations research in the sense of the scientific field, which is concerned with the use of quantitative and mathematical methods to solve administrative problems, which allows to measure the relationship between variables and make predictions.

- Operations and production management, which represents the knowledge field involved in helping FAO to produce goods and services efficiently.

\subsubsection{School of Systems: (Kenneth Boulding)}

This school relies on the concept of order as a basic idea based on its founder Ludvig Von Beertalanffy, a physicist and biologist, who defined the theory of public order as the whole organized or complex unit that combines and connects objects or parts that together form a unified structure. Studying any of these parts individually is not conducive to the true picture, 
an integrated set of parts that work together, to achieve a specific goal.

The organization, from Boulding view, resembles an organism as a system that interacts with the surrounding environment, consisting of parts or subsystems, each of which exercises a particular function or functions and is affected by each other as well as its impact on the institution as a whole. It is the case that more than one part of one or more systems work more successfully than if each part worked alone. There is a closed system that does not interact with the environment and an open system that reacts actively and passively (Human geological systems, social systems, and business).

\subsubsection{Posture (Attitude) School}

This school went on to study management based on incapable applicability of a general theory of the administrative process in a comprehensive and general manner. So the supporters of this school see that there is a relationship between the administrative process and the environment in which the practice is conducted for this process and therefore a strong correlation and a strong relationship between administrative actions and the characteristics around concerned with the situation of management with the environments and the adoration of administrative practice in the framework that corresponds to the course of the situation. Manager is able to adapt all his actions to fit the situation with its integrated dimensions.

There can be neither a uniform pattern of leadership and relationships between managers and subordinates, nor an equal degree of decentralization and decentralization, nor a single mode of communication in the administrative process. It is summarized in a perspective that matches management practices and position requirements to determine a better way of doing things.

\section{Management in Ali's Thought}

Ali bin Abi Talib in his administrative thought proceeds from a holistic vision based on solid logical rules, characterized by characteristics that are not time bound and applicable everywhere.

The administrative thought is a human thought that views the administration in a humane way, which is the human being with his nature and composition, how to deal with life, his views on it, the problems he faces and the resulting of progress and decline.

Humans have factors of strength and weakness, and as far as activating the factors of goodness and mobilizing their potential, institutions and projects that are under good management progress. The administrative institutions as seen by Ali community in which all the elements that need to be organized in a template in which efforts are combined to achieve the objectives set, and here arises the need for proper guidance as well as effective control based on proper planning according to intensive coordination.

A good leader is one who knows the nature of the people he deals with, knows what drives them, what discourages them, when they progress and when they retreat.

Therefore, for more than 1400 years, the Ali established a comprehensive constitution that 
draws people their rights, guarantees their interest, and diagnoses the State's duties towards them in various social, political, economic, security and administrative fields.

The Ali was keen to explain every commandment and a statement of wisdom from every advice he gives. He sees that his responsibility and duties towards his companions and his aides are a statement of purpose and interest in what he recommends and orders to follow, in order to guide them and excuse them from negligence and default in their assignment.

Anyone who holds an administrative position should know that he is not the first in this position, but that he should look to his predecessor in order to increase his successes and disappointments. The person in charge of that position should be compassionate and loving to the parish and to treat them purposefully away from humiliation and reduce the ills in their behavior and productivity. Workers in the institution are the basis and the manager or leader must be fair in respecting their wages pushing out of injustice from the oppressed and taking the right to the worker and the institution.

Ali made justice the basis of dealing with individuals, whether at the level of the institution or the level of the entire state. Participation in the decision (consultation, counseling) was considered the mainstay of the success of the leader; therefor he supported the idea of being guided by the right opinions distant from stingy, miserliness, cowardice and lack of vision!

Your worst ministers will be the men who had been a minister to the tyrannical and oppressive rulers before you, and who had been a party to atrocities and savage cruelties committed by them. Such persons should not hold your confidence and should not be in your trust, because they have aided sinners and have helped and assisted tyrants and cruel rulers, in their stead you can comfortably find persons who are equally wise and learned, but who have not developed sinful and criminal mentalities, who have not helped tyrants in their tyrannies nor assisted sinners to carry on sinful deeds. Such persons will prove least troublesome to you. If you take them in your confidence they will serve their connections with your opponents. Keep such people with you as your companions in your unofficial gatherings and in your durbars (See Appendix A). And here Ali teaches us that the good minister who holds the burden of people and serve their cause in life and in decent living, he carries their burden not being a nightmare on them! Neither Excellency nor exaltation, but far from flattery was the commandment of Ali for us and all generations. The philanthropist and the abuser are not equal, and examining of scholars is one of the most important commandments of the Ali for each leader or holder of responsibility, whether in a private or public institution. Ali recommends the governor and the leader with several ethical commandments that represents the principals of moral education for people. 


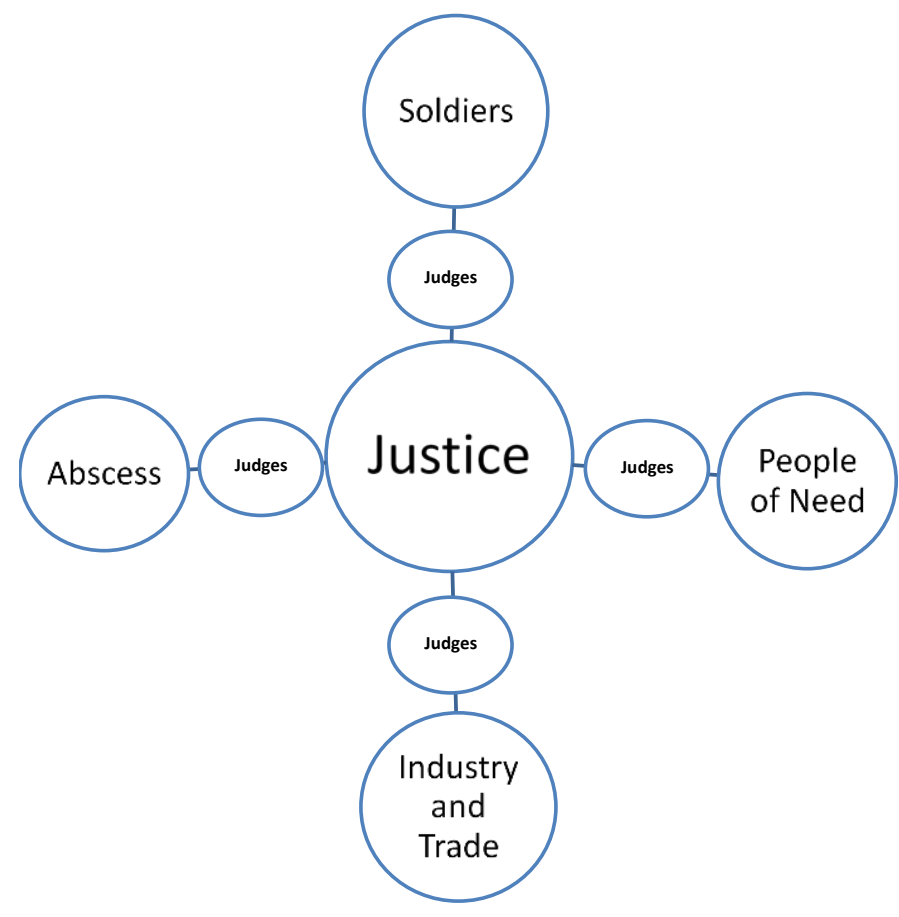

Scheme 1. Management plan in Ali's thought

Ali's system starts from the mind: one's mind is his system; the mind is the source of thought and the center of planning and the basis of programs. The mind puts resembles the system in our hands before application, and the question about its application is the good relationship that grow in society that are based on a basis of mutual rights and among those rights are the rights of the ruler over the parish and the right of parish on the governor, (speech section 216) and the principle of mutual rights, which forms the basis in the formation of the administrative system arises social relations between individuals, not based on the individual interests of the immediate or ethnic or national bond and The Preparedness for collective cooperation and synergies without neglecting the role of morality and virtue, and so the system turns to approaching life after being the idea in the mind and thus enters from the theory into practice.

One of the pillars of the system or strengthening the system is justice, which symbolizes the stick held by that who wanted to balance his body over a thin rope. Without it, the holder could not balance himself because he is prone to fall at any moment, so justice is a stick to organize society above the rope of cruel life and the way to the balance until society is upright.

The administration can only be established between groups of people who form a society. This society must have links. Society is the structure in which the administration is established and here lies the importance of the social environment in the advancement and 


\section{Macrothink}

prosperity of management and vice versa.

Management at Ali is a group of qualities and characteristics, including organization where there is no management without organization and system, and secondly humanity, because what is moving and activate management is human, it is necessary to publicize the human and know the strengths and weaknesses to address them, and thirdly the social situation that the administration is a society in which human relations and development In which the collective spirit. When this administration moves, the whole society moves as a result of the strong links that exist between management and society. Fourth, the goals that society seeks through good governance, which must be consistent with the goals of humanity in life and strive to achieve them through actions and ethics or what is known as human virtues.

The strategic planning as a function of contemporary administrative functions and characterized by a sound approach to achieve the objectives set first Ali great importance in his reign attested by modern concepts and policies that emphasize the vision of the future and predicted as a systematic mental process to choose the best possible means to achieve specific goals.

Ali also talked about the most important laws of modern economics, determine the prices of the result of supply and demand and this is done through fairness of the two parties ruled by the view of man and considering justice as the basis of equity, neither the seller does not overwhelmed the buyer nor the buyer to the seller. Trade should go on between the purchasers and suppliers according to correct measures and weights, and on such responsible terms that neither the consumer nor the supplier should have face losses. In this context it should be recalled that in the economic literature it is attributed to French economist Leon Valras (Leon Walras) (the discovery of the theory of the general (balance) equilibrium between supply and demand and the resulting price of different goods.

Below is a figure showing this balance.

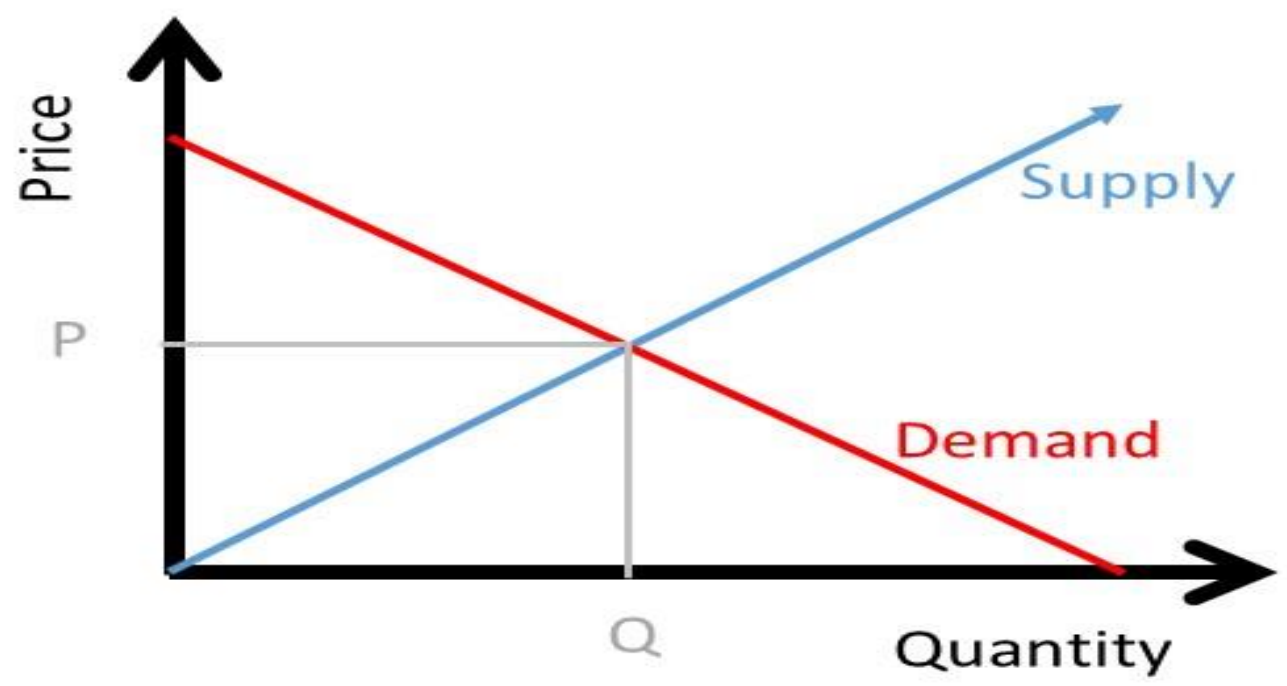

Figure 1. General equilibrium theory discovered by Leon Walras 
In this form, supply and demand are balanced (with the implication of equilibrium between market demand and supply) when the two curves meet at point $X$, in which case the price of equilibrium is $(\mathrm{P})$ and the quantity produced Selling them at this price is represented by point (Q).

This is a testimony of Leon Walras for what Ali reported on the balance of prices (see Appendix B).

\subsection{Organization}

Basic administrative process to study the structure of the administration and its objectives, tasks and responsibilities and methods of work in order to enable them to provide the services that were created for them at the lowest possible cost and the shortest reasonable time and the greatest productivity, and to this process essential components composition administrative apparatus - the composition of units - the administrative sequence - the distribution of administrative authority - Coordination between units. It also has various rules: the unit of command / unit of the presidency / equal responsibility with the authority / the assignment of duties and responsibilities of the post (see Appendix C) means the designation of a leader and responsible for each administrative activity capable of control.

\subsection{Orientation}

Guidance is a structured process in the form of steps and plans, and guidance set by the entrepreneur or leader of individuals and a certain group of people, to help them achieve their goals properly, in the sense of guiding subordinates and clarify the objectives of the work and means of accomplishing the joint cooperation based on satisfaction and response and mutual trust and a policy based right In fulfilling the aspirations of the overwhelming majority of the people, the parish aspires to the justice of the governors and revolts in the face of the oppressor and exhausting (see Appendix D).

\subsection{Censorship}

Means to ensure that work is taken in accordance to the rules and assets established with the aim of repairing errors and correcting the warp and punishing idlers and rewarding those who work sincerely and productivity. It is an important administrative processes because it aims to ensure the quality of performance and good production and to achieve the objectives set in management with the accompanying the correct management guidance and work on developing and reforming.

Ali has his own philosophy of censorship, which is based on an insightful vision of human and other goals to be achieved, which is concerned primarily with human humanity and the maintenance of his dignity and the protection of his rights, accompanied by moral values such as honesty, sincerity and integrity which a person is entrenched against social diseases (stealing, bribery, cheat, fraud, forgery, embezzlement, disclosure of secrets). Here, it turns out the noble goal and great goal of Ali. (See Appendix E, F).

These words and other words establish a great social philosophy and carry a high moral thought aimed at raising the social level of individuals and achieve a distinct social justice 
and provide a safe environment and elevate society to the high degrees to touch perfection.

First censorship is subjective, before it is popular and general, but the human insight on himself, a psychological immunity of the ruler, and therefore Ali emphasizes the principle of strict self-censorship to stimulate conscience and altruism and to keep one self under restraint when extravagant and inordinate yearnings and cravings try to drive someone towards wickedness and sin, because usually self tries to incite. So man should make his mind the source and fountained head of good thoughts, good intentions, and good deed. This can only be attained by keeping a strict control on desires. Good behavior in the management of people and their leadership and guidance are essential pillars (see Appendix G).

Calling to pay attention to the general public censorship because people criticize and judge (see Appendix H).

Public opinion is a major source of pressure on the ruler and institutions at all levels.

\subsection{Leadership}

Is the art of dealing with people, and this art is the supervisory activity practiced by a particular person on others in certain ways and to achieve specific goals. The leader is the master of that art and seeks with his staff and their methods and communication and control to achieve the desired goals and the progress and success of the administration depends to a large extent on the presence of competent leader on top. The level of management derives from the people in charge. (See Appendix I, P). There are qualities and qualifications that must be available in the leader abbreviated in several theories, including the theory of attributes of perception of purpose, enthusiasm, integrity, pacifism, intelligence and faith, the theory of the great man and the theory of gratification and the theory of attitude and interactive theory.

The theory of the great talented strongman feat that influences the group, the theory of saturation requires the leader to be able to satisfy the basic desires and needs of the group he leads. The attitude theory is aimed at discovering leaders by assessing their behavior, the depth and validity of their opinions, and their intelligence and stability.

The interactive theory leads to considering the administrative leader who can respond and interact with all those who surround him and his work, human elements and human, social, functional, physical and other factors; leadership is based on mercy for people, love and kindness towards them. (See Appendix J).

Thus, all theories are summarized in leadership.

\subsection{Staff Selection and Isolation Policies}

The task of selecting employees is the backbone of the Personnel Management Policy and one of the most important administrative processes because the success of the Department in implementing the policy laid down to it depends largely on the extent of good selection of the competent employee and the appointment of a job that suits his qualifications, abilities and preparations and thus put the right employee in the right place. History testifies to the fact 
that poor selection of staff has inevitably corrupted management (See Appendix K). Ali has the best way in electing employees, where they must be tested and experience and has a side of impartiality and good conduct and behavior.

\subsection{The Government}

An integrated government based on a holistic vision of the dimensions of the universe, man and life and the implementation of consultations and benefit from the expertise of specialists in various fields.

The document includes the "era" of the most important ideas and concepts of political and economic affairs of governance and management, but one of the most important pillars of intellectual, political and administrative sent by Ali to his prefects (viceroys).

This covenant outlines the general policy that rulers must adopt in every time or period on the basis of humanitarian principles, which aim to organize political, social and economic life accurately and build internal relations in society on the basis of justice, freedom and equality, whether the ruler deals with the parish or with the men of power. In accordance with a policy that guarantees stability and progress for all, it also clarifies the basis of foreign relations with the enemy and the friend in a way that preserves the nation's dignity, pride and complete independence (See Appendix M).

The state formed in the era (period) of Ali is a state based on the central system based on the subordination of the subordinate to the President and receive instructions and implementation on the other hand, (on the problem of the system of government) adopted a system of non-exclusive (relative administrative centralization) so that workers and employees have very wide powers to make political decision under The control and supervision of the governor, who is based in the capital, where the legislative authority is in the hands of the governor, then the executive and judicial authorities, and then to the rest of the institutions within a coordinated hierarchy.

With respect to the cabinet, Ali adopted reputable elements and clean desires following the conduct of close follow-up by sitting with the people and listening to their problems accompanied by a secret device to monitor the movement of workers and government employees, which helps to make a proper decision in isolation and nomination. He established an economic system that allows the individual to meditate within the policy of land revitalization and encouraged economic and agricultural development and he eliminated cronyism, bribery and twisted methods.

\subsection{The Ruler}

The ruler's relationship with the parish stems from the insightful view that the ruler is a member of the society and the most responsible before it. Thus, all barriers and considerations that prevent contact with the parish and understand their problems are abolished. Offering away from the parish has wide negative repercussions on the relationship of the ruler with the parish where it loses its trust in him. Ali has made the condition of justice for each ruler to share his emotions and feelings with all members of his society and thus Ali 
originate establishing a moral policy and political ethics, which is a driving force of progress and development and can eliminate all backwardness and bankruptcy. The ultimate goal is justice and right. Human beings are equal in character and no differentiation between them in treatment and rights on the basis of color, race, richness and poverty. All of them are equal before the law, and Ali himself is not exempted from this. There are no privileges and immunity of his own. He considers himself responsible before the law if he fails to perform the judgment properly, to serve the people (see Appendix J).

This document is a declaration of human rights and citizenship toward the authority or government, giving rights to the individual towards the ruler and the ruler towards the individual and defining their responsibility towards the other. A very important thing in the reign of Ali is the parish's aspiration to the justice of the governors, who passed by the rulers in the oppressive governments before his government, so they looked into the oppression of the people and exhausted them.

Ali entrusted the ruler to show people justice and to deal with them with a policy of pure right (see Appendix M).

\subsection{Abscess}

Ali refers to the role of taxes in the development of the economy, as there is a relationship between the tax imposed on producers and the services that should be provided by the state, and political and social issues, if the ruler demanded the tax as a social right performed by producers is on the other hand demands to reform the land and reconstruction and raise its status Productivity. The State shall provide the parish with the means necessary to increase production as well as to secure the necessary political and life conditions for them. (See Appendix N)

\subsection{Soldiers}

The role of the army is to defend the people, defend the land and state institutions, and maintain internal security. Since the military leaders vary in their activity and degree of awareness, therefore, it is necessary to standard the perfect to know good leadership, efficiency alone and capacity alone is not enough as long as not accompanied by social values. Military officers should receive highest respect and consideration, who pay most attention to the needs of soldiers under their command, who come forward to help the soldiers with their personal means and property, so that the soldiers may lead a happy and contented life and may have full confidence about the future of their families and children. If they are thus satisfied and are free from anxieties and care, then they will bravely and whole-heartedly fight out the battles which they will have to face. Constant attention towards the officers and the soldiers will make them love the leader more and more. (See Appendix O) 


\subsection{Authorities Assigned to the Governor}

\subsubsection{Judiciary}

Ali pointed to the independence of the judiciary and to the conditions that must be met in the judge, it is not rigid thought, which narrows things when the diversity of litigations or multiple litigation, and be patient and avoid the use of pressure, intensity and roughness with the opponents, and that the judge does not insist on his mistake Take an unfair judgment and then prove the right to the contrary must correct his mistake and not be satisfied with the opinion of the initiator of the adversaries, but must be carefully investigated and scrutinized strongly during the search process (See Appendix P). Judge should be someone who is not overcome in his attempt to ascertain the truth by the obstinacy of the litigants. It has to be said that this is an allusion to the person with whom the litigants are satisfied. When the judge is given an elevated position, the ruler's favorites as well as the common people will be in awe of him and no one will dare slander him, out of fear of the ruler and respect for the person held in such high esteem by him.

Ali concludes in this regard a logical case in which he refers to the difference of judges in the judgments, the difference in one case is evidence of their weakness of the origins of deduction.

\subsubsection{Social Solidarity}

"People are two kinds, either your brother in religion or your counterpart in creation" (Man is either your brother in faith or your equal in humanity).

A pioneering wisdom, a call for reform, caring for others, aiding, supporting and introducing pleasure to the heart of human beings, doing all that would do, and doing everything that would relieve their distress, eliminate their needs, draw closer to them, satisfy them, and satisfy them with the emotional aspect that contributes to closer bonds of solidarity and exchange between human beings. It is the best model to be followed in this emotional and humanitarian aspect, especially in these painful material conditions experienced by mankind, which imposes on the individual not to show indifference towards them and tries to absorb them in a spirit of politeness, communication and compassion, these are an important part in human relations and brotherly bonds People)

This right was launched by Ali in his theoretical and applied method (best courtesy relief grieved) (Starving the poor is the result of enjoyment of the rich)

In his daily tasks, Ali has made addressing the problem of poverty and destitution and embodying it a social symbiosis and a civilized project that meets the needs of the poor (see Appendix Q). A good society cannot be formed without taking people out of poverty and lifting them out of indigence before being pushed the to commit sin, monument, looting and horror for a living. "Beware the reaction of the gracious (kind) if hungry and miscreant (varmint) if full." (See Appendix G)

"Poverty was almost ungrateful (infidel)." When this relief and compassionate spirit exists in a society, its stability and prosperity will be consolidated. 
Ali, the most wonderful leader and ruler committed before this moral school on himself, I persuade myself to say this Prince of the believers and do not share them in the hatred of eternity, or be like them in the roughness of living) And when he knew that his worker on Basra Osman bin Hanif was invited to a feast he wrote to him Saying: you, son of Hanif, I was told that you were invited to a banquet, so you rushed to, and multi food colors were conveyed to you. You should not assent to.

This universal human spirit of love and compassion is a guarantee so that the social complications will radically address all human beings.

A blind man asked, Ali said who is this? They said that he is a Christian man. Ali said: "you used him and when he grew older and unable to work, you withheld money for him? Give him as much as he need."

Ali is concerned with all human communities and social groups alike, Ali is the artist and the mind and the perfect engineer who worked on improving his society and integration, the best that popularizes love, brotherhood, affection and equality among its members.

George Jurdak is a Christian scholar and researcher who became fascinated with the inspirational and educational guidelines of Ali for building the individual as well as societies. Because of his extreme liking and admiration he was motivated for undertaking a thorough research; the fruits of these painstaking efforts were the outcome of a precious and novel book titled: "Ali - the Voice of Justice for Humanity". (Jurdak, 2010)

George Jurdak's innovation consists of comparison of "International Declaration for Human Rights" with the famous historical letter written to Malik al-Ashtar after carefully reviewing the "International Declarations for Human Rights" item by item, compares them with the words of Ali, and then with logical reasoning proves the superiority of basics and principles of human and social rights presented by Ali 1400 years ago. After analyzing, comparing, and appraising, George Jurdak explains the four basic differences, and through the undeniable realities lifts the curtain from the false and demagogic faces of world arrogance.

In order to explain the importance and greatness of Ali's views regarding human rights as well as to introduce his exaltedness about the principles and laws in a complete, explicit, and comprehensive manner; it was found necessary to quote the most important points regarding "International Declarations for Human Rights" so that any one themselves could appreciate the differences between them.

But if we have to speak some short words in this field, it must be pointed out that in principle it would be very difficult to find any difference between the school of Ali and the "International Declaration of Human Rights". Of course considering the differences of time, slight differences in the contents and details are inevitable, but overall from the point of view of base and criteria, there exist no single clause in the "International Declaration for Human Rights" issued by the United Nations, for which an exact and similar clause does not exist in the charter issued by Ali. Apart from this in the charter and principles issued by Ali, one may discover things superior and higher than the matters incorporated into the International Charter of Human Rights." 
About the important differences between these two George Jurdak writes as follows:

"If there exist any genuine difference between these two international laws, in my opinion it consists in their implementation, which could be defined into three items as follows:

1. The first difference is that the International Declaration for Human Rights has been prepared by the joint efforts of thousands of learned intellectuals selected by a majority or representatives of all the governments, while the text and legal principles of a live constitution have been the outcome of a single exalted personality named Ali Ibn Abi Talib.

2. The second difference is that Ali has issued his declaration of human right at least ten centuries ahead of the "International Declaration for Human Rights" issued by the United Nations.

3. The third difference is that the authors of the International Declaration for human Rights or more correctly the collectors of relevant material and principles from various resources, regarding the task accomplished by them, or the task which they wanted to accomplish, filled the whole world by overemphasizing the greatness of their task and exaggerating their self-praise to the extent that human conscience and intellectual taste became disgusted with all that vain boasting.

Because of their egotism and arrogance they exhausted the people and forced them to praise for thousands and more heavy obligations which they have placed upon the shoulders of the people and nations, While, on the other hand Ali acted with courtesy and humility towards the masses of the people and never aspired for superiority and greatness, rather sincerely asked for the pardon from the masses for his negligence and omissions in discharging of his obligations.

With regard to his research efforts, about all-around and divine like personality of Ali, George Jurdak comments: "Since I am a Christian by faith, no one could accuse me of being sentimental or prejudiced in my admiration of Ali".

\section{Conclusion}

Having clearly and unequivocally illustrated the major schools of administration in the last two centuries, and having questioned the opinion of Ali in all the facilities of government, authority and meeting, we found that the management materials provided by all known administrative schools testify unequivocally to the thought of Ali, addressing the administration from the perspective of building the land on the basis of justice, efficiency and equity. Therefore, we consider that venerable scholars, whatever their religion, creed or race, are just witnesses to the correctness, validity and comprehensiveness of Ali's thought, not only in the twenty-first century, but we can say objectively as a testimony to all ages, because a country ruled by justice and the view of man as a great value It is the basis of building, uplift the land, which is reflected on the renaissance of companies and institutions.

\section{Acknowledgment}

I would like to extend my sincere thanks to my colleague Prof. Dr. Mahmoud Murad and my 
daughter Dr. Issraa Shahine for their outstanding ideas that contributed to the correction and directing of this study, which enabled me to take it to the shore of safety of the management economy.

\section{References}

Babeau, A. (1970). Malinvaud (E.)-Leçons de théorie microéconomique. Revue économique, 21(5), 868-868. https://doi.org/10.2307/3499814

Barnard, C. I. (1968). The functions of the executive, 11. Harvard university press.

Bennis, W. G. (1975). Le développement des organisations. Dalloz, Paris.

Drucker, P. (1980). Learning from foreign management. The Wall Street Journal, 4(24).

Drucker, P. F. (1954). The Practice of Management-New York: Haper e Row.

Duncan, O. D. (1949). Max Weber: The Theory of Social and Economic Organization.

Goetz, B. E. (1949). Management planning and control: a managerial approach to industrial accounting. McGraw-Hill.

Herzberg, F., Mausner, B., \& Snyderman, B. B. (1959). The Motivation to Work, John Wiley \& Sons. Inc., New York, 195.

Jurdak, G. (2010). Ali the Voice of Justice for Humanity. Beirut, Lebanon. Alandalos Press.

Kopelman, R. E., Prottas, D. J., \& Davis, A. L. (2008). Douglas McGregor's theory X and Y: Toward a construct-valid measure. Journal of Managerial Issues, 255-271. https://doi.org/10.1037/e518532013-388

Likert, R. (1961). New Patterns of Management. New York. McGraw-Hill Book. Co. The free Press.

Plunkett, W. (2002). Richard Management: meeting and exceeding customer expectations/Warren R. Plunkett, Raymond F. Attner, Gemmy S. Allen.-7th ed. Darien: South-Western.

Taylor, F. W. (1911). The principles of scientific management New York. NY: Harper \& Brothers.

Thelen, H. A. (1949). Group dynamics in instruction: Principle of least group size. The School Review, 57(3), 139-148. https://doi.org/10.1086/441592

Walras, L. (1954). Elements of Pure Economics, translated by W. Jaffe. Homewood: Irwin.

\section{Appendix}

A. Truly the worst of your ministers are those who were the ministers of the evil (rulers) before you and shared with them in their sins. Let them not be among your retinue, for they are aides of the sinners and brothers of the wrongdoers. You will find the best of substitutes for them from among those who possess the like of their ideas and effectiveness but are not 
encumbranced by the like of their sins and crimes; who have not aided a wrongdoer in his wrongs nor a sinner in his sins. These will be a lighter burden upon you, a better aid, more inclined toward you in sympathy and less intimate with people other than you. So choose these men as your special companions in privacy and at assemblies.

B. Let selling be an openhanded selling, with justly balanced scales and prices which do not prejudice either party, buyer or seller. As for him who lets himself be tempted to hoard after you have forbidden him (to do so), make an example of him and punish him, but not excessively.

C. Appoint to the head of each of your concerns a chief from among these men, (a person) who is neither overpowered when these concerns are great nor disturbed when they are many. Whatever fault of your secretaries you overlook will come to be attached to you.

D. Let the dearest of your affairs be those which are middlemost in rightfulness, most inclusive in justice and most comprehensive in (establishing) the content of the subjects. For the discontent of the common people invalidates the content of favorites, and the discontent of favorites is pardoned at (the achievement of) the content of the masses.

E. Then inspect the affairs of the soldiers as parents inspect their own child. Never let anything through which you have strengthened them distress you, and disdain not a kindness you have undertaken for them, even if it be small, for it will invite them to counsel you sincerely and trust you.

F. Never let the good-doer and the evil-doer possess an equal station before you, for that would cause the good-doer to abstain from his good-doing and habituate the evil-doer to his evil-doing. Impose upon each of them what he has imposed upon himself.

G. Control your desire and restrain your soul from what is not lawful to you, for restraint of the soul is for it to be equitous in what it likes and dislikes.

H. People will look upon your affairs in the same way that you were wont to look upon the affairs of the rulers before you. They will speak about you as you were wont to speak about those rulers. And the righteous are only known by that which God causes to pass concerning them on the tongues of His servants.

I. Then choose to judge among men him who in your sight is the most excellent of subjects, i.e., one who is not beleaguered by (complex) affairs, who is not rendered ill-tempered by the litigants, who does not persist in error, who is not distressed by returning to the truth when he recognizes it.

J. Infuse your heart with mercy, love and kindness for your subjects. Be not in face of them a voracious animal, counting them as easy prey, for they are of two kinds: either they are your brothers in religion or your equals in creation. Error catches them unaware, deficiencies overcome them, and (evil deeds) are committed by them intentionally and by mistake. 
K. Then look into the affairs of your administrators. Employ them (only after) having tested (them) and appoint them not with favoritism or arbitrariness, for these two (attributes) embrace different kinds of oppression and treachery.

L. Never reject a peace to which your enemy calls you and in which is God's pleasure, for in peace there is ease for your soldiers, relaxation from your cares and security for your land. But be cautious, very cautious, with your enemy after (having made) peace with him, for the enemy may have drawn near in order to take advantage of (your) negligence. Therefore be prudent and have doubts about trusting your enemy in this (matter).

M. Know that there is nothing more conducive to the ruler trusts his subjects than that he be kind towards them, lighten their burdens and abandon coercing them in that in which they possess not the ability. So in this respect you should attain a situation in which you can confidently trust your subjects, for trusting (them) will sever from you lasting strain. And surely he who most deserves your trust is he who has done well when you have tested him, and he who most deserves your mistrust is he who has done badly when you have tested him.

N. Investigate the situation of the land tax in a manner that will rectify the state of those who pay it, for in the correctness of the land tax and the welfare of the taxpayers is the welfare of others. The welfare of others will not be achieved except through them, for the people, all of them, are dependent upon the land tax and those who pay it. Let your care for the prosperity of the earth be deeper than your care for the collecting of land tax, for it will not be gathered except in prosperity. Whoever exacts land tax without prosperity has desolated the land and destroyed the servants (of God). His affairs will remain in order but briefly.

O. Among the chiefs of your army favor most him who assists the soldiers with his aid and bestows upon them what is at his disposal to the extent that suffices both them and the members of their families left behind. Then their concern in battle with the enemy will be a single concern, for your kind inclination toward them will incline their hearts to you.

P. Then choose to judge among men him who in your sight is the most excellent of subjects, i.e., one who is not beleaguered by (complex) affairs, who is not rendered ill-tempered by the litigants, who does not persist in error, who is not distressed by returning to the truth when he recognizes it, whose soul does not descend to any kind of greed, who is not satisfied with an inferior understanding (of a thing) short of the more thorough, who hesitates most in (acting in the face of) obscurities, who adheres most to arguments, who is the least to become annoyed at the petition of the litigants, who is the most patient (in waiting) for the facts to become clear and who is the firmest when the verdict has become manifest; a man who does not become conceited when praise is lavished upon him and who is not attracted by temptation. But such (men) are rare. Thereupon investigate frequently his execution of the law and grant generously to him that which will eliminate his lacks and through which his need for men will decrease. Bestow upon him that station near to you to which none of your other favorites may aspire, that by it he may be secure from (character) assassination before you by men of importance. 
Q. Take upon yourself the upkeep of the orphans and aged from among those who have no means at their disposal and do not exert themselves in begging. (All of) this is a heavy burden upon rulers. The truth, all of it, is a heavy burden.

R. Then there is the lowest class, the needy and wretched, those who have the right to aid and assistance.

\section{Copyright Disclaimer}

Copyright for this article is retained by the author(s), with first publication rights granted to the journal.

This is an open-access article distributed under the terms and conditions of the Creative Commons Attribution license (http://creativecommons.org/licenses/by/4.0/). 